\title{
Attitudes and Perceptions of University Students on Climate Change: Evidences from an International Study
}

\section{Walter Leal Filho}

Research and Transfer Centre "Sustainable Development and Climate Change Management and Hamburg University of Applied Sciences

\section{Desalegn Yayeh Ayal ( $\square$ desalula@gmail.com )}

Center for Food Security Studies, College of Development Studies, Addis Ababa University,

\section{Tony Wall}

International Centre for Thriving, University of Chester, Chester, United Kingdom

\section{Chris Shiel}

Department of Life \& Environmental Science, Faculty of Science \& Technology, Bournemouth University, Poole

\section{Arminda Pac}

Universidade da Beira Interior, NECE-UBI (Research Centre for Business Sciences), Rua Marquês D'Ávila e Bolama 6201-001 Covilhã

\section{Paul Pace}

Centre for Environmental Education and Research, University of Malta, Msida 2080, MSD

\section{Mark Mifsud}

Centre for Environmental Education and Research, University of Malta, Msida 2080, MSD

\section{Amanda Lange Salvia}

Graduate Program in Civil and Environmental Engineering, University of Passo Fundo

\section{Antonis Skouloudis}

University of Verona, Department of Business Administration

\section{Sara Moggi}

College of Charleston, Sustainability Literacy Institute, Charleston

\section{Todd LeVasseur}

SEPA-interea Research Group in Social Pedagogy and Environmental Education. Universidade de

Santiago de Compostela

\section{Garcia Vinuesa Antonio}

University of Aveiro

\section{Ulisses M Azeiteiro}

University of Aveiro

Nikolaou loannis 
Democritus University of Thrace, Department of Environmental Engineering, Faculty of Engineering

\section{Marina Kovaleva}

European School of Sustainability Science and Research, Hamburg. University of Applied Sciences

\section{Research Article}

Keywords: Attitude, climate change, curriculum, education, perceptions, students, universities

Posted Date: January 20th, 2022

DOI: https://doi.org/10.21203/rs.3.rs-1179074/v1

License: (c) (i) This work is licensed under a Creative Commons Attribution 4.0 International License. Read Full License 


\section{Attitudes and Perceptions of University Students on Climate Change: Evidence from an International Study}

Walter Leal Filho ${ }^{1}$, Desalegn Yayeh Ayal ${ }^{2 *}$, Tony Wall ${ }^{3}$, Chris Shiel ${ }^{4}$, Arminda Paco ${ }^{5}$, Paul Pace $^{6}$, Mark Mifsud ${ }^{7}$, Amanda Lange Salvia ${ }^{8}$, Antonis Skouloudis ${ }^{9}$, Sara Moggi ${ }^{10}$, Todd LeVasseur $^{11}$, Garcia Vinuesa Antonio ${ }^{12}$, Ulisses M Azeiteiro ${ }^{13}$, Nikolaou Ioannis ${ }^{14}$, Marina Kovaleva ${ }^{15}$

1. Research and Transfer Centre "Sustainable Development and Climate Change Management", Hamburg University of Applied Sciences, Ulmenliet 20, D-21033 Hamburg, Germany, walter.leal2@haw-hamburg.de ORCID 0000-0002-1241-5225

2. Center for Food Security Studies, College of Development Studies, Addis Ababa University, desalula@gmail.com

3. International Centre for Thriving, University of Chester, Chester, United Kingdom, t.wall@chester.ac.uk

4. Department of Life \& Environmental Science, Faculty of Science \& Technology, Bournemouth University, Poole, UK, cshiel@bournemouth.ac.uk

5. Universidade da Beira Interior, NECE-UBI (Research Centre for Business Sciences), Rua Marquês D'Ávila e Bolama 6201-001 Covilhã, apaco@ubi.pt

6. Centre for Environmental Education and Research, University of Malta, Msida 2080, MSD, Malta, paul.j.pace@um.edu.mt

7. Centre for Environmental Education and Research, University of Malta, Msida 2080, MSD, Malta, mark.c.mifsud@um.edu.mt

8. Graduate Program in Civil and Environmental Engineering, University of Passo Fundo, Campus I-BR 285, São José, Passo Fundo, RS 99052-900, Brazil, amandasalvia@gmail.com

9. Department of Environment, University of the Aegean, Mytilini, Greece, skouloudis@env.aegean.gr

10. University of Verona, Department of Business Administration, via Cantarane 24 - 37129 Verona, Italy, sara.moggi@univr.it

11. College of Charleston, Sustainability Literacy Institute, Charleston, US, levasseurtj@cofc.edu

12. SEPA-interea Research Group in Social Pedagogy and Environmental Education. Universidade de Santiago de Compostela, a.garcia.vinuesa@usc.es

13. Department of Biology and CESAM - Centre for Environmental and Marine Studies, University of Aveiro, Aveiro, Portugal, ulisses@ua.pt.

14. Democritus University of Thrace, Department of Environmental Engineering, Faculty of Engineering, Greece, inikol@env.duth.gr

15. European School of Sustainability Science and Research, Hamburg. University of Applied Sciences, Ulmenliet 20, 21033 Hamburg, Germany, Marina.Kovaleva@haw-hamburg.de

$\left({ }^{*}\right)$ Corresponding author

\section{Abstract}

Universities have an unrivalled potential to educate students on climate change issues and to actively engage them in climate affairs, both as citizens and influencers of future professions. Despite this potential and the many advantages of student engagement in climate change, 
less emphasis has been given to understanding students' perceptions and attitudes towards climate change, in a way that may guide changes in the curriculum and teaching practices. Based on the need to address the existing literature gap, this paper assesses university students' perceptions and attitudes towards climate change at the international level. This study comprises a survey of a sample of universities across the world and uses descriptive statistics to identify the most important trends across geographical locations of the universities. The study provides recommended actions that universities may enact in order to improve educational provisions in matters related to climate change and, by doing so, better prepare future professionals to cope with the challenges of a changing climate.

\section{Keywords}

Attitude, climate change, curriculum, education, perceptions, students, universities

\section{Universities and climate change}

Climate change undermines the achievement of global sustainable development, and hence it requires the engagement of various actors and immediate solutions. The role of universities in contributing generally to sustainable development and in particular to climate change adaptation and mitigation is well documented. Sustainable development has become a significant field of research that describes how universities should contribute and fulfil their responsibilities (Barth and Rieckman, 2013). There is a widespread view that universities have a key role to play in carbon reduction by reducing their own greenhouse gas emissions through campus greening and by working with other local actors (O'Malley, 2019; Godwell and Nompe, 2014). Universities also have a wider role to play in the development of climate change initiatives and mitigation programs (Pitt and Congreve, 2017; Læssøe and Mochizuki, 2015; Altan, 2010; UNESCO; 2010; Knuth et al., 2007), local community awareness creations, and capacity building interventions (Shiel et al., 2015). Where universities pursue integrative approaches (Filho et al., 2015), the universities not only reduce carbon emissions but may also educate students in carbon reduction approaches, using the campus as a living lab for learning and climate solutions. The university campus is an entity that consumes a considerable amount of energy, counterbalanced by the infrastructure to practice greenhouse gas emissions reduction measures as well as influence on the attitude of the university community (Katzy, Pawar and Thoben, 2021; Cordero, Centeno and Todd, 2020). As such, the approaches adopted in universities have the potential to influence behavioural change, whereby students develop the confidence and knowledge to make choices that have a positive impact on energy consumption (Cordero, Centeno and Todd, 2020; Cotton et al., 2016).

For the purposes of this paper, the term "climate change education" is used to refer to education pedagogies that are used to teach about and raise awareness of climate change. The universities' climate change education programme is vital for equipping students with basic and advanced skill and knowledge and for influencing their behaviour and lifestyle, resulting in actions to adapt and mitigate climate change impacts throughout their lifetime that can also influence future generations (Choi, Oh and Lutzenhiser, 2017; UNESCO; 2010; UN, 1992). Climate change education can also create a path for students to initiate climate change activism and work with various actors (Cordero, Centeno and Todd, 2020). Despite the importance of climate change education in responding to impacts of climate change, less attention has been given to systematically assessing the attitude, perceptions, and practices of students and the integration of the climate topic in the higher education institutions' curricula and co-curricular activities in a way that may guide changes in the curriculum and teaching practices. There is a research need for studies aimed at a better understanding of the 
perceptions of university students on climate change. This paper fills the literature gap and highlights the importance of climate education in higher education institutions.

The theoretical and practical aspects of climate change can be embedded at universities through two main perspectives: mitigation and adaptation (Fussel and Klein, 2006). Mitigation mainly refers to actions carried out to reduce the contribution of activities and services to climate change (Skanavis et al., 2017), and adaptation policies are pursued to avoid or reduce the adverse effects of climate change on vulnerable communities and infrastructure (Fussel, 2005; Owen et al., 2013). It is suggested that universities have a significant role in implementing climate change adaptation and mitigation measures (Carlin, 2010) with a variety of approaches available (Cortese, 2003), including building sustainable development and climate change into the short and long-term visions of universities. If universities adopt such approaches, concrete change within institutions will eventually be achieved (Filho, 2010a). However, climate change concerns should also extend to a rethinking of university policies, strategies, action plans (Dagiliūtè et al., 2018) and disclosures (Moggi, 2019; Larrán et al., 2019), whereby greater attention is given to the specific aspects of sustainability through a holistic approach. This is an approach where sustainable development is integral to the universities' missions and top-level strategies and which is then embedded and reflected in educational programmes and teaching practices, research projects, and actions that engage students and the local community (Filho et al., 2019b).

Empirical work suggests that universities are more active in improving energy efficiency in buildings and equipment to meet their emissions targets than in increasing their share of renewables in energy consumption (Filho et al., 2019a). Having control over planning and construction decisions, universities get an opportunity to adopt 'green building practices' and apply for a Leadership in Energy and Environmental Design (LEED) certification for renovated and new buildings (Liu and Ren, 2020).

Similarly, despite the increasing research into education for sustainable development (ESD), (see, for example, Sterling et al., 2013; Vare and Scott, 2007) few papers refer specifically to climate change education. Universities have been identified as having a key role in educating students about the social and environmental challenges the world currently faces (MolthanHill et al., 2019), but there is less detail on what education on reducing carbon should include. In line with this, Filho (2010b) reinforced, over a decade ago, that education about climate change specifically should be the most significant priority. He explained that, while sustainability education operates at the macro level, climate change education should be seen as an equally important micro level unit: they are inter-related, intertwined, and mutually reinforcing. As he explains:

The impact of human activities on ecosystems and the control in emissions of greenhouse gases are, for example, two of the many items which need to be better understood if long-term solutions for the problems posed by climate change are to be found (Filho, 2010b, p.1).

Here, it is argued that universities need to extend climate change education beyond the traditional technical subjects, emphasising the importance of opening up ways to foster a deeper understanding of climate change and ensuring that students have a broader and deeper understanding of the challenges.

\section{Climate change and student involvement}

Organisations such as the United Nations (UN) and United Nations Educational, Scientific and Cultural Organization (UNESCO) have been stressing the need for climate change education, and this is reflected in the ever-growing significance to young people (Kuthe et al., 
2020; Körfgen et al., 2017). As argued by Akrofi et al. (2019), increasing student awareness through education is crucial in fostering active participation to promote climate change actions at all levels of the community. Thus, universities need to inspire both students and staff to become involved with the challenges brought by climate change so that they become active agents, promoting research, developing solutions for climate change mitigation/adaptation, and even taking a leading role in the political field (Molthan-Hill et al., 2019). Efforts should be made to develop educational programmes that are designed to increase climate literacy and empower students to move towards sustainability (Burkholder et al., 2017).

Student involvement in climate change adaptation and mitigation is critical (e.g. AbuQamar et al., 2015; Ayanlade and Jegede, 2016; Freije et al., 2017; Haq and Ahmed, 2020; Mobley et al., 2010; Mugambiwa and Dzomonda, 2018; Ojomo et al., 2015). However, Akrofi et al. (2019) found that 'students' involvement in climate change-related workshops and campaigns significantly influenced their knowledge levels whilst their membership of climaterelated student clubs had no significant influence' (p. 1). This was partly related to activities that did not explore 'key issues such as involving knowledge on indirect causes (such as meat consumption) and effects (such as conflicts and gender inequalities) of climate change' (ibid, p. 2). Similarly, according to Akrofi et al. (2019), students' attitudes and behaviours are dependent on their level of awareness and knowledge about climate change issues, and as a consequence, their experience will depend on their level of participation in climate change courses, workshops and campaigns, membership in environmentalist groups, and access to climate information.

University students' perceptions of climate change are not a settled research agenda (e.g. see Haq and Ahmed, 2020; Freije et al., 2017; AbuQamar et al., 2015). Their perceptions of climate change vary across disciplines in which they are enrolled (Haq and Ahmed, 2020). Beck et al. (2013) attested that the students from the faculty of science had significantly greater knowledge about climate change than the students of engineering and business and education. Similarly, Ayanlade and Jegede (2016) reported that graduates in environmental sciences had more class experience in climate change than those in other courses. In South Africa, university students from the faculty of science and agriculture had greater knowledge of climate change than those of the health sciences and humanities (Mugambiwa and Dzomonda, 2018). In this specific study, results seem to suggest that students might not be well informed about what climate change is, but they do have an understanding of the threats to society. In Bahrain, Freije et al. (2017) reported that more than half of the sample responded correctly to the questions designed to test their level of knowledge about climate change. No significant differences were observed between newly admitted students and those attending higher academic levels, suggesting that students have mainly increased their knowledge through general education, rather than through their academic education at university (AbuQamar et al., 2015).

In Nigeria, Ojomo et al. (2015) examined the knowledge and attitudes of the causes, effects, and priority given to climate change amongst university students and government officials. Around $90 \%$ of the participants identified human activity as the cause of climate change. Moreover, the study highlighted that personal experiences shaped the attitude of individuals. Additionally, individuals were more informed about the causes of climate change than about its effects. The students' knowledge and awareness about climate change and its causes are due to their exposure to extreme climate impacts, formal education, the internet and international media (Agboola and Emmanuel, 2016; Ayanlade and Jegede, 2016). In turn, the level of their knowledge and practical experience could shape their perceptions and influence adaptation and mitigation responses (Myers et al., 2012). This suggests that the students' knowledge and perceptions of climate change and responses are prerequisite and are the outcome of their exposure to education, information, and socio-cultural and work experiences (Ayanlade and Jegede, 2016). Therefore, universities need to broaden their educational 
efforts to ensure that graduates understand the commonly accepted scientific concept of climate change and its causes in order to become part of the solutions (Wachholz et al., 2014). However, since students have not reached the desired level of consciousness, educational curriculums on climate change need to be designed to positively affect students' perceptions about the environment, and their courses should aim to improve university students' scientific skills and knowledge and shape their attitudes and beliefs (Shaman and Knowlton, 2017).

Mugambiwa and Dzomonda (2018) indicated that a lack of climate change literacy was found in some cases, with university students not actively participating in formal programmes and organised activities aimed at dealing with climate change. Mobley et al. (2010) reported that the majority of students were not involved in environmental organisations. Furthermore, Mobley and his associates indicated that the majority of students, both involved and not involved in environmental organisations, attributed climate change to human activities. Among the students who participated in the environmental organisations, a few associated climate change with supernatural activity, while others linked it to both supernatural and human activity. Thus, it is possible to affirm that perceptions about climate change may vary according to participation, or lack thereof, in an environmental organisation. In sum, whilst evidence highlights differences in the perceptions and understanding of climate change between disciplines, there is a gap in understanding students' perceptions and attitudes towards climate change in a way that would guide changes in the curriculum and teaching practices. Table 1 provides an overview of some studies on university students and climate change.

Table 1. Examples of studies on increasing awareness of climate change at universities

\begin{tabular}{lll}
\hline Initiative & Country & Literature \\
\hline $\begin{array}{l}\text { Students' attitude and perceptions of } \\
\text { climate change }\end{array}$ & $\begin{array}{l}\text { Portugal, Mexico, } \\
\text { and Mozambique }\end{array}$ & Morgado et al. (2017) \\
\hline $\begin{array}{l}\text { Teaching about climate change for } \\
\text { students in health-related disciplines }\end{array}$ & China & $\begin{array}{l}\text { Yang et al. (2018) } \\
\text { Maxwell and Blashki (2016) }\end{array}$ \\
\hline $\begin{array}{l}\text { Teaching on climate change and health } \\
\text { education }\end{array}$ & Columbia & Shaman and Knowlton (2017) \\
\hline $\begin{array}{l}\text { Teaching about adaptation to climate } \\
\text { change; knowledge for action }\end{array}$ & Montreal Canada & Lapaige and Essiembre (2010) \\
\hline $\begin{array}{l}\text { Students' knowledge and perceptions } \\
\text { about the health impact of climate change }\end{array}$ & Ethiopia & Nigatu et al. (2014) \\
\hline $\begin{array}{l}\text { Students attitude toward sustainability } \\
\text { issues and climate change }\end{array}$ & Australia & Eagle et al. (2015) \\
\hline $\begin{array}{l}\text { Students climate change awareness } \\
\text { Students perception on climate change }\end{array}$ & Taiwan & Di Giusto et al. (2018) \\
\hline $\begin{array}{l}\text { Students understanding on climate change } \\
\text { and sustainability }\end{array}$ & Australia & Pfautsch and Gray (2017) \\
\hline
\end{tabular}

These examples illustrate the variety of works that have been performed. But despite these 218 efforts, there are still many research gaps.

\section{9}


The levels of knowledge, attitudes, perceptions and engagement of university students in climate change were assessed by using an online, administered questionnaire survey at the global level. The questionnaire was designed in a way that may guide changes in curriculum development and teaching practices, using the existing literature and in consultation with the research team of Inter-University Sustainable Development Research Programme (IUSDRP). IUSDRP is an academic network of 139 member universities interested in sustainable development research, and they entail over 700.000 students (please visit the website for member universities details). Furthermore, the authors reviewed the survey questions to avoid redundancy and to ensure that all relevant issues were considered. The survey questionnaire included 21 questions and was pre-tested and adjusted based on the feedback from 10 experts in the areas of climate change and sustainability at different universities. The full questionnaire was also designed to collect general information and ensure that details were anonymous (Appendix $A$ ).

The online survey was conducted from 16th September to 30th November 2020 using Survey Monkey (https://www.surveymonkey.com/). The survey was disseminated via email, providing a web link with access to the online instrument (in English) to students attending universities within the Inter-University Sustainable Development Research Programme (IUSDRP). Participation was voluntary, and authors had no influence or control over who participated; hence, there was no self-selection bias. A total of 424 questionnaires were received from 41 countries around the world. The most represented region was Europe with $45.3 \%$ of the replies, followed by North America (14.9\%), Africa (14.6\%), South America $(12.5 \%)$, Asia $(7.8 \%)$ and Oceania $(5 \%)$. Figure 1 shows the countries participating in the study.

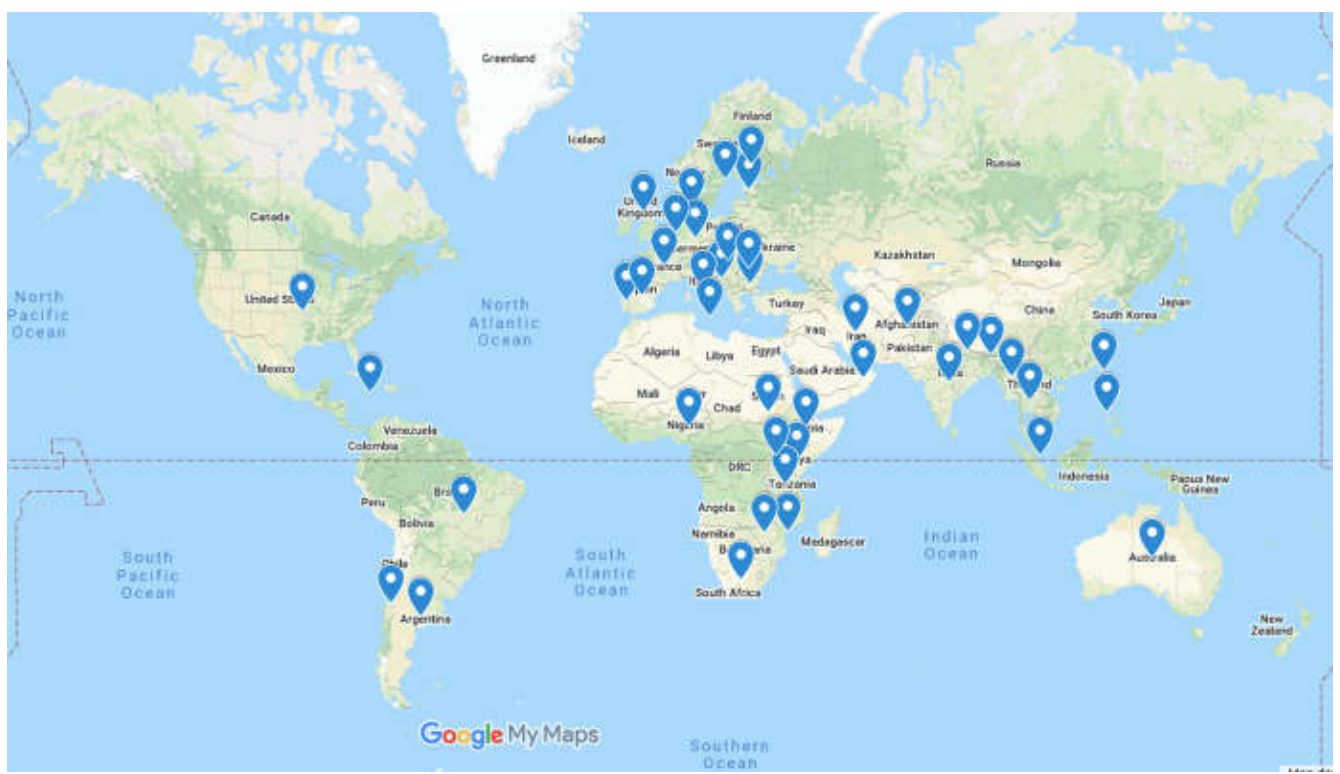

Figure 1. Countries from which questionnaires were returned

To adequately explore and provide an accurate view of the result of the possible differences and relationships between university students' attitudes and perceptions on climate change, the questionnaire survey participants were grouped into six categories according to the UN geoscheme in order to be able to perform the statistical analysis: Africa, Asia and Pacific region, Europe, Latin America and the Caribbean, North America, and Oceania. Following Luepsen (2018), the Variance analysis (ANOVA) test was conducted to explore statistical differences between scale variables whose mean values can be measured (CCCo and CCAS). The t-student test was conducted to explore statistical differences between two independent variables in order to get further insight into the ANOVA test results. The 
Pearson Chi-square test was conducted for categorical variables (CCO and CCC). The Spearman's rank correlation coefficient (rho) was measured to assess possible relationships between variables. This coefficient was selected as it does not require the assumption that the relationship between the variables is linear, nor does it require the variables to be measured on interval scales' (Hauke and Kossowski, 2011, p. 89).

260

261

262

263

264

265

266

267

268

269

270

\section{Results}

This section describes the findings, which were explored in relation to climate change occurrence (CCO), knowledge about its causes (CCC), and the concern about the problem (CCCo). Five further items explored aspects related to climate change awareness (CCA).

\subsection{Descriptive results on knowledge, beliefs and concern about climate change}

As depicted in Table 2, more than $88 \%$ of the participants indicated that climate is definitely changing, while $10.4 \%$ felt climate is probably changing. It seems clear that the majority of university students were certain about the changing climate. However, provided that climate change and its impending dangers are real, those doubtful university students should be convinced.

In Table 2, it can be seen that almost $70 \%$ of the respondents rightly attributed the cause of climate change mainly to human activity. Nevertheless, about $13 \%$ of the respondents 'wrongly gave equal weight to the naturally induced and human-induced climate change. Likewise, $15 \%$ of the respondents believe that climate change is entirely caused by human activity. This is clear evidence that universities should revisit their curriculum and cocurricular activity to shape the attitude and perceptions of students on climate change causal attribution. This is because university students, regardless of their discipline, could play important roles in their university and within the community if they understand the real causes of climate change.

The results related to the respondents' concerns about climate change are shown in Table 2. Around $18 \%, 36 \%$, and $42 \%$ of respondents were somewhat worried, very worried, and extremely worried about climate change-related risks, respectively. However, $4 \%$ of respondents were not worried about the adverse impacts of climate change. The variation of the level of concern could be connected with either their exposure to climate change-related risk or the weather information dissemination platform and approach. However, in general, an extremely high level of worry or ignorance could demotivate university students in taking climate change adaptation and mitigation action. Extremely high levels of concern could undermine their actual capacity to respond to the adverse impacts of climate change, and an equally optimist attitude could hinder students in understanding the reality of climate change and its impact. The students' contributions to the direct climate change adaptations and mitigations within their university - as well as the implementation of measures in their lifetime within the community - depend on their balanced judgment of the causes of climate change.

Table 2. General answers about climate change occurrence, causes and concern

\begin{tabular}{|l|l|l|l|l|}
\hline \multicolumn{2}{c}{ The climate is... (\%) } & Climate change is... (\%) & How worried are you about climate \\
change? (\%)
\end{tabular}


The university students' awareness about climate change is the result of their direct exposure to climate-related risks, participation in climate change-related events, dialogue and news. As illustrated in Figure 2, more than $50 \%$ of the respondents were aware of the Sustainable Development Goal 13 target, are up-to-date in the climate change debate, and understand climate change adaptation and mitigation measures. To the contrary, the majority of the respondents were not aware of the discussions and outcomes of the Conferences of the Parties (COPs). Hence, the students' involvement is low in the follow-up of climate change-related events and discussions in different platforms.

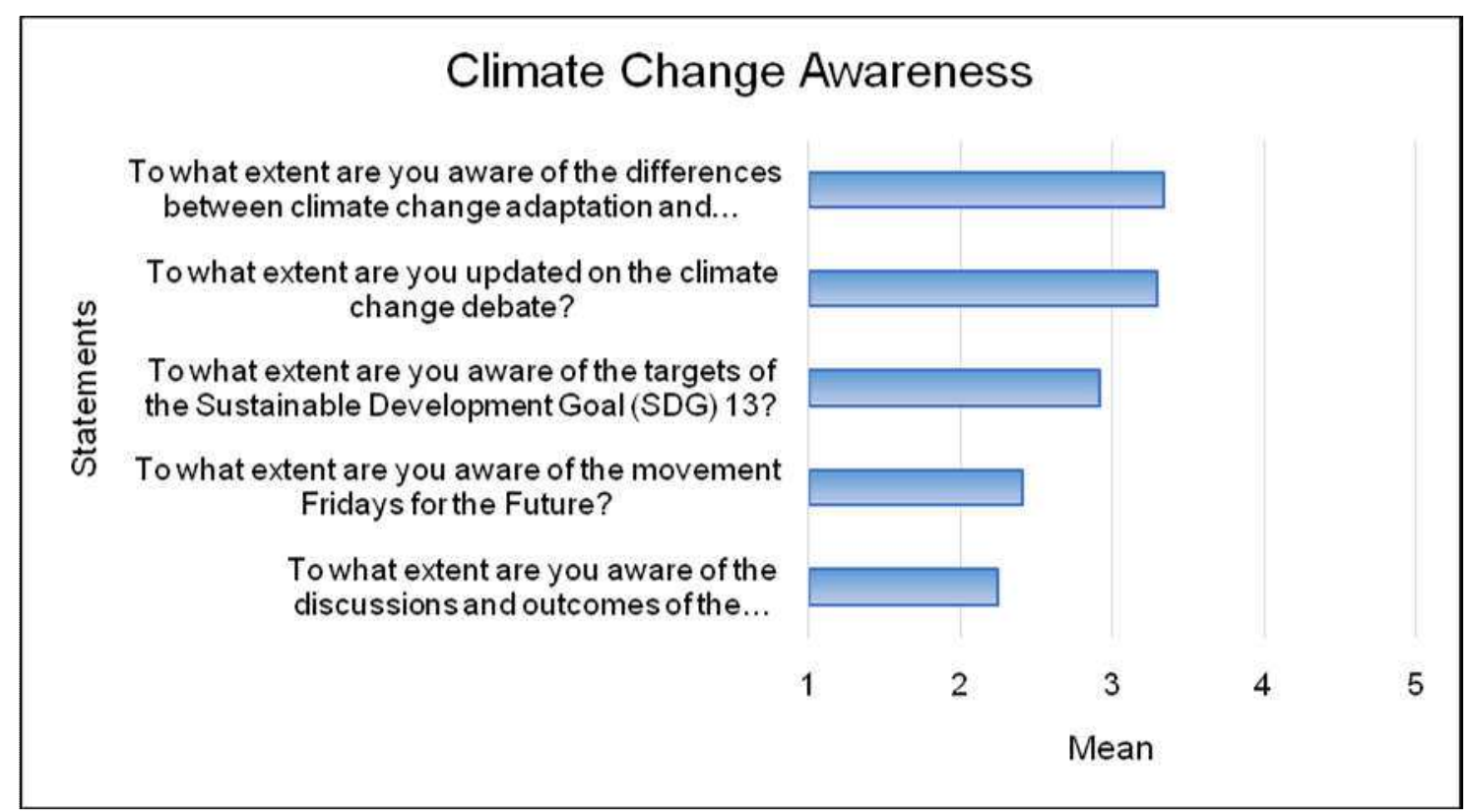

302

Figure 2. Mean values of the five statements of Climate Change Awareness.

The Spearman's rho result shows that there is a positive relation between the respondents' concern and their awareness of climate change (correlation coefficient of $.350^{*}, p=.000$ ). The result suggests that the more concerned the university students are, the more aware they will be about climate change. The result suggests that universities could improve student awareness by organising climate change-related themes in discussion sessions and incorporating them in the curriculum and co-curricular activities.

The outcomes of ANOVA and t-student, the Pearson Chi-square test and the correlations analyses (rho) are presented below:

\subsubsection{Regions}

The results of 41 nationalities were aggregated into 6 categories according to the UN geoscheme. Figure 3 shows the mean values regarding CCO, CCC, CCCo and CCA. Subsequently, Table 2 displays the t-student results. Statistically significant differences are shown in bold in Table 2 for $p<0.05$.

Fig. 3 illustrates that the majority of participants in all regions mainly attributed climate change to human activities. The university students' climate change causal attribution is in agreement with the literature (IPCC, 2019, Ojomo et al., 2015). However, a regional variation of climate change causal attributions was observed amongst the university students. For instance, the great majority (85\%) of participants in North America, followed by Oceania (78\%), attributed climate change mainly to human activity. Likewise, about $28 \%$ of participant university students in the Africa region associated climate change equally with 
human activity and natural processes. In the Asia and Pacific region the proportion of university students stating that climate change is caused by human and natural factors was equal with those who attributed its cause entirely to human activity. There were no participants in Oceania who linked climate change equally with human activity and natural processes. The university students' causal attribution variation to climate change could be due to variations in exposure to climate change education, climate risks, participation of cocurricular activities, media, dialogue and differing socio-cultural backgrounds (Agboola and Emmanuel, 2016; Ayanlade and Jegede, 2016). Climate change education could shape university students causal attribution and perceptions. Consistent with our argument, Ochieng and Koske (2013) reported that awareness is a means for strengthening individuals and the wider community.

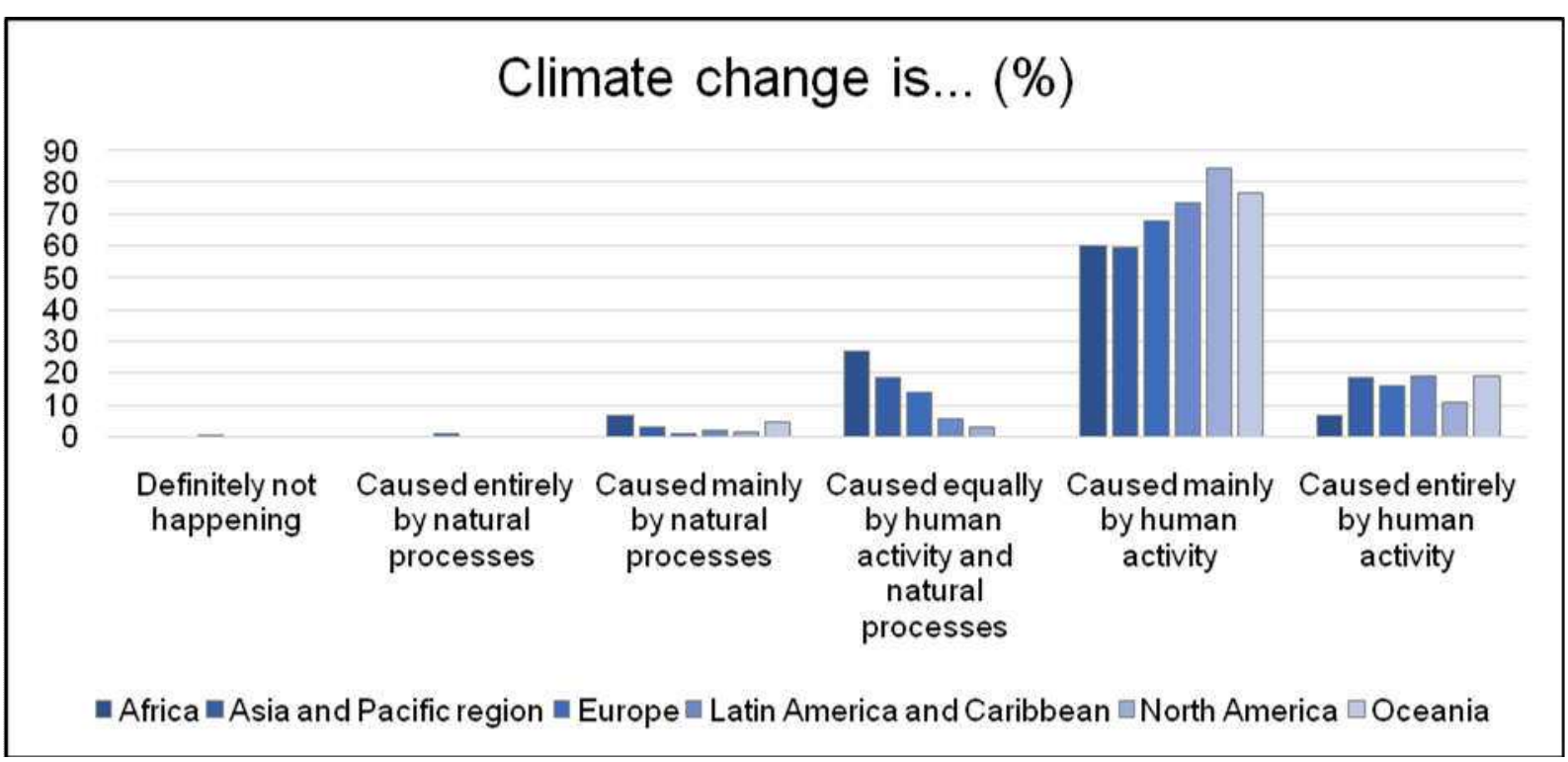

Figure 3. Outcomes regarding participants' residence: Climate change causes. Pearson Chi-square test did not offer statistical differences $(p>0.05)$

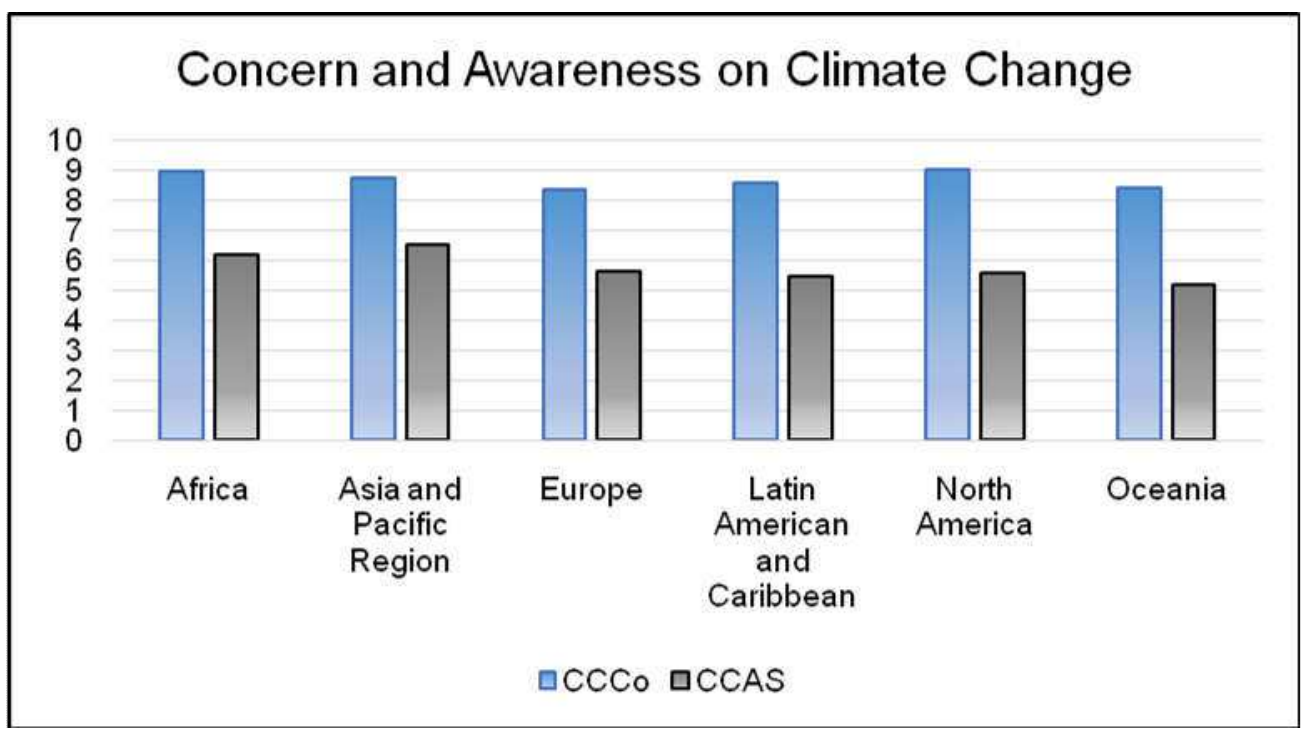

Figure 4. Outcomes regarding participants' residence. CCCo (Climate Change Concern) and CCAS (Climate Change Awareness Scale) averages. The results are presented in a scale of 10 . 
As depicted in Figure 4 and Table 3, some regional differences were observed among participants in relation to climate change concern and awareness. Participants from Asia and the Pacific region were significantly more aware than participants from Europe, Latin America and Caribbean, North America and Oceania. Likewise, participants from Africa were more aware about climate change than other regions except Asia and the Pacific region. Participants from Africa, North America, and the Asia and Pacific region were more concerned about climate change, while participants from Europe and Oceania demonstrate less concern about climate change, followed by Latin America and the Caribbean region. The regional results show that the higher the awareness of participants, the greater the concern about climate change. The regional level of climate change awareness and climate change concerns in Asia and the Pacific region, Africa and North America could be attributed to the participants' exposure to climate risks.

Table 3. T-student significance values by sets of data regarding participants' origin

\begin{tabular}{|c|c|c|c|c|c|c|c|}
\hline & Africa & \multicolumn{3}{|c|}{$\begin{array}{c}\text { Asia and } \\
\text { Pacific Region }\end{array}$} & \multirow[t]{2}{*}{ Europe } & \multirow[t]{2}{*}{$\begin{array}{c}\text { Latin } \\
\text { American and } \\
\text { Caribbean }\end{array}$} & \multirow[t]{2}{*}{ North America } \\
\hline Africa & - & & & & & & \\
\hline $\begin{array}{l}\text { Asia and Pacific } \\
\text { Region }\end{array}$ & $\begin{array}{l}\text { CCCo } \quad(\alpha \quad> \\
0.05) \\
\text { CCA }(\alpha>0.05)\end{array}$ & & - & & & & \\
\hline Europe & $\begin{array}{l}\text { CCCo }(\alpha= \\
0.007) \\
\operatorname{CCA}(\alpha>0.05)\end{array}$ & $\begin{array}{l}\text { CCCo } \\
0.05) \\
\text { CCA } \\
\mathbf{0 . 0 1 2 )}\end{array}$ & $\begin{array}{l}(\alpha \\
(\alpha\end{array}$ & $>$ & - & & \\
\hline $\begin{array}{l}\text { Latin American } \\
\text { and Caribbean }\end{array}$ & $\begin{array}{l}\text { CCCo }(\alpha> \\
0.05) \\
\text { CCA }(\alpha>0.05)\end{array}$ & $\begin{array}{l}\text { CCCo } \\
0.05) \\
\text { CCA } \\
\mathbf{0 . 0 1 1 )} \\
\end{array}$ & $\begin{array}{l}(\alpha \\
(\alpha\end{array}$ & $>$ & $\begin{array}{l}\text { CCCo } \quad(\alpha \quad> \\
0.05) \\
\operatorname{CCA}(\alpha>0.05)\end{array}$ & 89 & \\
\hline North America & $\begin{array}{l}\text { CCCo }(\alpha> \\
0.05) \\
\text { CCA }(\alpha>0.05)\end{array}$ & $\begin{array}{l}\text { CCCo } \\
0.05) \\
\text { CCA } \\
\mathbf{0 . 0 1 7 )}\end{array}$ & $\begin{array}{l}(\alpha \\
(\alpha\end{array}$ & $=$ & $\begin{array}{l}\text { CCCo }(\alpha \quad> \\
\mathbf{0 . 0 0 2 )} \\
\operatorname{CCA}(\alpha>0.05)\end{array}$ & $\begin{array}{l}\text { CCCo }(\alpha> \\
0.05) \\
\text { CCA }(\alpha>0.05)\end{array}$ & - \\
\hline Oceania & $\begin{array}{l}\text { CCCo } \quad(\alpha> \\
0.05) \\
\text { CCA }(\alpha>0.05)\end{array}$ & $\begin{array}{l}\text { CCCo } \\
0.05) \\
\text { CCA } \\
\mathbf{0 . 0 1 3 )}\end{array}$ & $\begin{array}{l}(\alpha \\
(\alpha\end{array}$ & $=$ & $\begin{array}{l}\text { CCCo } \quad(\alpha \quad> \\
0.05) \\
\operatorname{CCA}(\alpha>0.05)\end{array}$ & $\begin{array}{l}\text { CCCo } \quad(\alpha> \\
0.05) \\
\text { CCA }(\alpha>0.05)\end{array}$ & $\begin{array}{l}\text { CCCo }(\alpha \quad> \\
0.05) \\
\text { CCA }(\alpha>0.05)\end{array}$ \\
\hline
\end{tabular}

Note: CCCo (Climate Change Concern); CCA (Climate Change Awareness). T-student statistical differences for $\mathrm{p}<0.05$ are presented in bold.

4.2.2. Socio-demographic and academic characteristics: gender, age, current study and area of study

Table 4 shows the descriptive analysis of the socio-demographic and educational status of respondents in relation to their awareness and concern about climate change and its causes. Concerning gender, variable statistical differences were only found in relation to climate change occurrence. Figure 5 shows the distribution of response percentages regarding the causes of climate change, where women tend to have declared in greater percentages than men that human activity is the main cause of climate change. To properly conduct the Pearson Chi-square test, the residual responses to the options of 'Definitely not happening' $(0.4 \%)$, 'Caused entirely by natural processes' $(1.2 \%)$ and, 'Caused mainly by natural processes' (4.4\%) were not included in the analysis.

Table 4. Respondents' climate change concern and climate change awareness based on social-demographic and academic variables 


\begin{tabular}{|c|c|c|c|c|c|c|c|}
\hline \multirow{2}{*}{\multicolumn{2}{|c|}{$\begin{array}{l}\text { Social-demographic and academic } \\
\text { variables }\end{array}$}} & \multicolumn{3}{|c|}{ Climate change concern } & \multicolumn{3}{|c|}{$\begin{array}{l}\text { Climate change } \\
\text { awareness* }\end{array}$} \\
\hline & & Mean & Median & SD & Mean & Median & SD \\
\hline \multirow{2}{*}{ Gender } & Female & 8.67 & 8.33 & 1.418 & 5.54 & 5.60 & 1.895 \\
\hline & Male & 8.48 & 8.33 & 1.493 & 5.90 & 5.60 & 1.948 \\
\hline \multirow{4}{*}{ Age $^{*}$} & $18-25$ & 8.60 & 8.33 & 1.421 & 5.39 & 5.20 & 1.860 \\
\hline & $26-35$ & 8.57 & 8.33 & 1.471 & 6.08 & 6.00 & 1.975 \\
\hline & $36-50$ & 8.48 & 8.33 & 1.698 & 6.20 & 6.80 & 1.916 \\
\hline & $51+$ & 9.16 & 10 & 1.259 & 7.08 & 6.80 & 1.300 \\
\hline \multirow{3}{*}{$\begin{array}{l}\text { Current } \\
\text { studies } \\
\text { level }^{*}\end{array}$} & Undergraduate & 8.51 & 8.33 & 1.534 & 5.17 & 5.20 & 1.770 \\
\hline & Post graduate & 8.56 & 8.33 & 1.353 & 6.15 & 6.40 & 1.820 \\
\hline & Doctoral & 9.06 & 10.00 & 1.327 & 6.84 & 7.20 & 2.125 \\
\hline \multirow{9}{*}{$\begin{array}{l}\text { Area of } \\
\text { study* }\end{array}$} & Education & 9.06 & 10.00 & 1.356 & 6.95 & 7.20 & 2.180 \\
\hline & Arts \& Humanities & 8.80 & 8.33 & 1.180 & 5.66 & 5.80 & 1.647 \\
\hline & $\begin{array}{l}\text { Social Sciences, } \\
\text { Journalism \& Information }\end{array}$ & 8.87 & 8.33 & 1.306 & 6.05 & 6.00 & 1.916 \\
\hline & $\begin{array}{l}\text { Business, Administration } \\
\text { \& Law }\end{array}$ & 8.33 & 8.33 & 1.561 & 5.00 & 4.80 & 1.755 \\
\hline & $\begin{array}{l}\text { Natural Sciences, } \\
\text { Mathematics \& Statistics }\end{array}$ & 8.64 & 8.33 & 1.519 & 6.17 & 6.00 & 1.80 \\
\hline & $\begin{array}{l}\text { Engineering, } \\
\text { Manufacturing } \\
\text { \&Construction }\end{array}$ & 8.26 & 8.33 & 1.463 & 6.10 & 6.40 & 1.797 \\
\hline & $\begin{array}{l}\text { Agriculture, Veterinary \& } \\
\text { Wildlife Management }\end{array}$ & 8.47 & 8.33 & 1.558 & 5.07 & 4.80 & 1.782 \\
\hline & Health \&Welfare & 9.33 & 10.00 & 1.165 & 6.28 & 6.40 & 2.158 \\
\hline & Biology \&Environmental & 8.90 & 8.33 & 1.167 & 7.07 & 7.20 & 1.832 \\
\hline
\end{tabular}

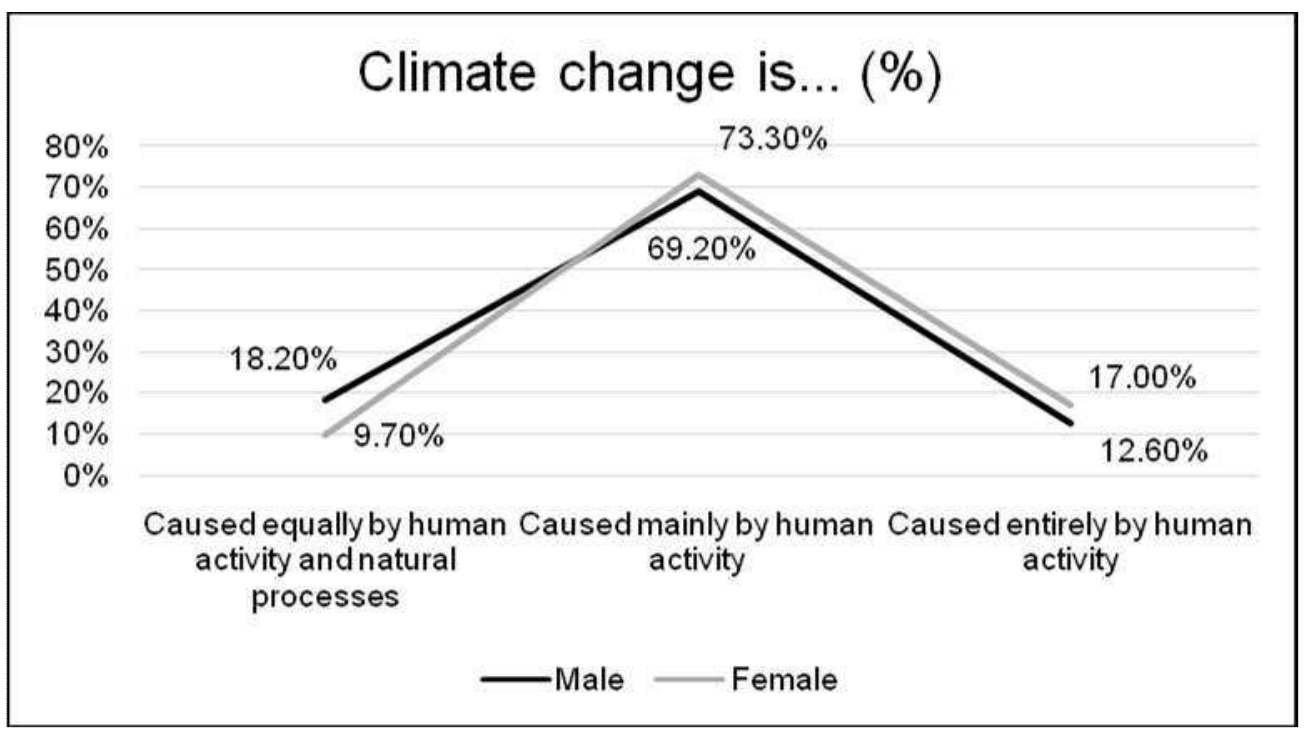

Figure 5. Pearson Chi-square test offered significance differences for $p<0.05(\alpha=0.033)$

Climate change awareness was the only variable where statistical differences were found (Table 4).

Table 5 shows the Spearman's rank correlation coefficient (rho) significant value of age and current study variables There are statistical differences when comparing the youngest participants (18 - 25 aged) with the others. Participants declared a greater awareness as their age increases. This conclusion is also supported by the Spearman correlation results, 
which indicate that there is a positive correlation (0.198) between age and awareness levels. Regarding study level, similar results were obtained as was expected, since a higher level of study is related with an older age. The correlation coefficient suggests a stronger relation when reaching a higher level of studies (0.311).

Table 5. Climate change awareness scale averages regarding age and current study level: $t-$ student and rho values.

\begin{tabular}{lccccc}
\hline Age & CCAS $(\mathbf{X})$ & $\mathbf{1 8 - 2 5}$ & $\mathbf{2 6 - 3 5}$ & $\mathbf{3 6 - 5 0}$ & $\mathbf{7 5 1}$ \\
\hline $\mathbf{1 8 - 2 5}$ & 5.39 & - & .001 & .010 & .018 \\
$\mathbf{2 6 - 3 5}$ & 6.08 & .001 & - & - & - \\
$\mathbf{3 6 - 5 0}$ & 6.20 & - & .010 & - & - \\
$>\mathbf{5 1}$ & 7.08 & - & .018 & - & -
\end{tabular}

\begin{tabular}{|c|c|c|c|c|}
\hline \multirow{2}{*}{$\begin{array}{l}\text { Spearman's } \\
\text { rho } \\
\text { Study level }\end{array}$} & \multicolumn{2}{|c|}{ Correlation coefficient } & \multicolumn{2}{|c|}{.000} \\
\hline & $\operatorname{CCAS}(X)$ & Undergraduate & Post-graduate & Doctoral \\
\hline Undergraduate & 5.17 & - & .000 & .000 \\
\hline Post-graduate & 6.15 & .000 & - & .034 \\
\hline Doctoral & 6.84 & .000 & .034 & - \\
\hline \multirow[t]{2}{*}{$\begin{array}{l}\text { Spearman's } \\
\text { rho }\end{array}$} & \multicolumn{2}{|c|}{ Correlation coefficient } & \multicolumn{2}{|c|}{ Significance } \\
\hline & \multicolumn{2}{|c|}{$.311^{*}$} & \multicolumn{2}{|c|}{.000} \\
\hline
\end{tabular}

Table 6 illustrates the significance values obtained through the t-student test regarding the area of study variable. The outcomes suggest that students enrolled in courses related to biology and the environmental studies declared the highest levels of awareness. To the contrary, those students that are enrolled in courses related to business, administration and law and/or agriculture, veterinary and wildlife management are the ones that declared the lowest climate change awareness.

Table 6. T-student, significant values regarding area of study

\begin{tabular}{lllllllllll}
\hline & $\begin{array}{c}\text { CCAS } \\
(\mathbf{X})\end{array}$ & Edu & A\&H & SS & Business & NS & Eng & Agric & H\&W & Bio/Env \\
\hline Edu & $\mathbf{6 . 9 5}$ & - & .019 & - & .000 & - & - & .000 & - & - \\
A\&H & $\mathbf{5 . 6 6}$ & .019 & - & - & .033 & - & - & - & - & .001 \\
SS & $\mathbf{6 . 0 5}$ & - & - & - & .002 & - & - & .010 & - & .028 \\
Business & $\mathbf{5 . 0 0}$ & .000 & .033 & .002 & - & .000 & .007 & - & .032 & .000 \\
NS & $\mathbf{6 . 1 7}$ & - & - & - & .000 & - & - & .001 & - & .023 \\
Eng & $\mathbf{6 . 1 0}$ & - & - & - & .007 & - & - & .019 & - & - \\
Agric & $\mathbf{5 . 0 7}$ & .000 & - & .010 & - & .001 & .019 & - & - & .000 \\
H\&W & $\mathbf{6 . 2 8}$ & - & - & - & .032 & - & - & - & - & - \\
Bio/Env & $\mathbf{7 . 0 7}$ & - & .001 & .028 & .000 & .023 & - & .000 & - & - \\
\hline
\end{tabular}

Note: -student significance values $(p<0.05)$. Edu = Education; A\&H = Arts \& Humanities; $S S$ = Social Sciences, Journalism \& Information; Business = Business, Administration \& Law; NS = Natural Sciences, Mathematics \& Statistics; Eng = Engineering, Manufacturing \& Construction; Agric = Agriculture, Veterinary \& Wildlife Management; H\&W = Health \& Welfare; Bio/Env = Biology \& Environmental

\subsubsection{Current and future engagement}

Current and future climate change engagement was explored through two items. Current engagement was assessed by the statement 'To what extent are you involved in the climate 
change movement?'. To explore possible relations, the Spearman's rank correlation coefficient (rho) was utilised. The results are shown in Table 6. Future engagement was assessed through the statement, "Would you like to participate in (more) activities related to climate change?'.

Regarding current engagement in climate change, all variables (except age) achieved significant positive results. The strongest relations included those on climate change concern and climate change awareness, which suggests that a greater concern and awareness is related to a greater current engagement. The same results, but with lower correlation values, were obtained regarding current study level; as the participants reach higher academic levels, they are more likely to participate in climate change activities.

Table 7. Correlation values (rho). Current engagement

\begin{tabular}{lllll}
\hline & Age & $\begin{array}{l}\text { Current } \\
\text { study } \\
\text { level }\end{array}$ & $\begin{array}{l}\text { Climate } \\
\text { Change } \\
\text { Concern }\end{array}$ & $\begin{array}{l}\text { Climate } \\
\text { Change } \\
\text { Awareness }\end{array}$ \\
\hline Current engagement & - & $.108^{*}$ & $.379^{*}$ & $.624^{*}$ \\
\hline
\end{tabular}

${ }^{*}$ Correlation is significance at the 0.01 level (2-tailed)

Concerning future engagement (Figure 6), most of the participants $(90.1 \%$ ) declared that they would like to participate in activities related to climate change. In this case, to be currently involved in climate change activities seems to be related to a greater engagement in participating in future activities.

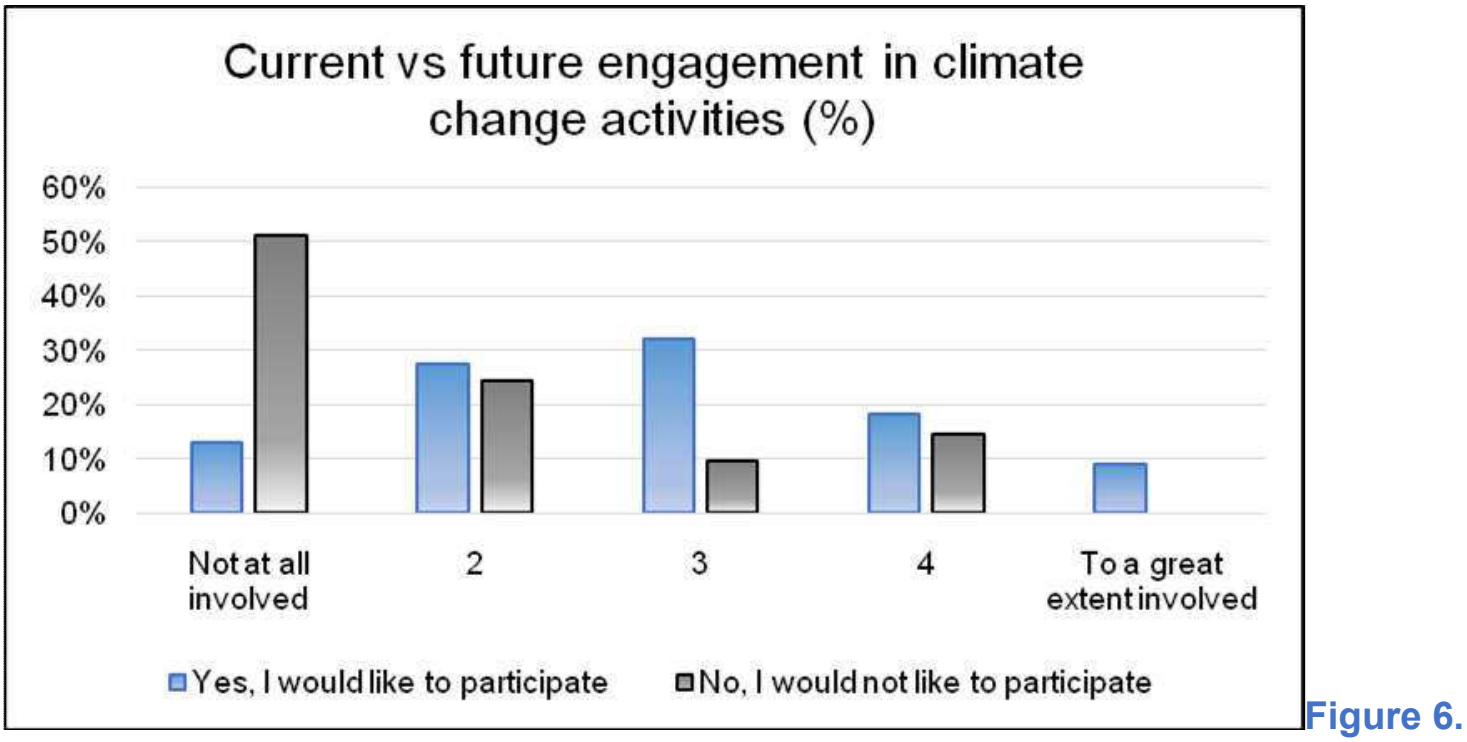

Pearson Chi-square test offered significance differences for $p<0.05(\alpha=0.000)$

\section{Discussion}

Climate change is a serious global developmental challenge that requires the integrated and coordinated action of all sectors and actors. However, society's awareness and concerns for climate change and its impacts vary according to differences in economy, demography, culture, educational level and background, and the degree of exposure to climate risks (Islam and Winkel, 2017; Kabir et al., 2016; Shahid and Piracha, 2016). University students form a vital segment of the community and can play a crucial role in the climate change adaptation and mitigation efforts within their university. Their education and involvement in the reality of 
changing climate and its impending risks is a means to equip these students with relevant skills and knowledge and to thereby influence the wider community to implement climate change adaptation and mitigation measures. Therefore, assessing the attitudes and perceptions of students can help universities understand their students' knowledge about climate change and its adverse impacts in order to adequately incorporate climate issues in the co-curricular activities and formal curriculum. Accordingly, this paper examined the perceptions of university students about the occurrences, causes and concerns of climate change and their future engagement in climate change adaptation and mitigation interventions.

This study indicates that the majority of respondents are aware of the climate change issue, and most expressed concerns about the impending risks associated with climate change. In line with Akrofi et al.'s (2019) study, there was a small percentage of students who expressed some doubt about the existence of climate change and therefore did not express concern about its effects. In contrast to previous studies, this study highlighted that students were seemingly more aware about broader climate change debates and the differences among change, adaptation and mitigation than about the specific initiatives, such as Conferences of the Parties or Fridays for the Future. This perhaps reflects the scale of awareness of broad debates, but also the possible challenge of more specific initiatives operated on a global basis. As such, this highlights the critical role of the promotion of engagement opportunities.

The proportion of students attributing climate change to human activity was larger than other studies (Ojomo et al., 2015), but lower than published studies on climate scientists (Cook et al., 2016). Females were significantly more likely than males to suggest that human activity is the main cause of climate change. Climate change awareness was highest in the Asia and Pacific Region, and climate change concern was highest in North America. This may reflect the proportion of the wider population and the recent increase in counter-narratives about climate change in the public media, particularly in terms of US policy and related protests. However, the differences between regions were not found to be statistically significant. As there were statistically insignificant differences between reported awareness and concern across continents, the study found general support for the logical and intuitive positive relation between awareness and concern. The wide support for understanding the causes of climate change also highlights the importance of social norms in attempting to prompt climate change adaptive behaviour (van Valkengoed and Steg 2019). As such, activities would benefit from promoting positive norms and addressing problematic norms in universities.

Although data suggest that females are reportedly less aware than males of climate change and are more concerned about the effects of climate change than males, there were no statistically significant differences. Similarly, whereas data suggested that people aged $51+$ were more aware and concerned about climate change, the most significant difference was found in the youngest age group (18-25 years old). A similar pattern existed for the educational level, where climate change awareness and concern broadly increased from undergraduate to postgraduate levels. These findings contrast with some studies that suggest similar levels of awareness across levels (AbuQamar et al, 2015), but support others that indicate differences in experience over time (Ayanlade and Jegede 2016). This study suggests that there are increasingly strong relationships between age and climate change awareness, perhaps where age and education might act as a proxy for personal experience and the ability to emotionally receive and make sense of the complexity of climate change issues.

This study reflected the findings of other studies that indicated different levels of awareness across disciplines but also provided comparative data in relation to concern for climate change. In this study, climate change awareness and concern varied between disciplines, from the lowest relative awareness in business, administration and law (similar to Beck, 2013 , in terms of awareness) and the lowest relative concern in engineering, manufacturing 
and construction. In contrast, the highest level of awareness was in the disciplines of biology and the environmental sciences (similar to Mugambiwa and Dzomonda, 2018), and the highest level of climate change concern was in health and welfare. These findings were statistically significant and as such provide a new global analysis of disciplines in relation to each other in terms of climate change awareness and concern. This suggests the different ways that climate change is positioned and understood in relation to other disciplinary concepts, which filter through to levels of awareness and concern (Wachholz et al., 2014). Institutional or country level approaches may promote more consistency in addressing such diversity.

In terms of current engagement in climate change initiatives, all variables (apart from age) demonstrated significant positive relationships, and the strongest relationships were identified in climate change awareness and concern and current study level. At the same time, those currently not involved in these initiatives were the most likely to express a continuation of non-involvement. This suggests an association between student concern and their intentional behaviour to change an underlying dissonance related to that concern (Grothmann and Patt, 2005; van Valkengoed and Steg, 2019). This indicates that special efforts might be required to reach this particular group, but that clarity will be needed on what the climate change issues are and why they are significant to the person and discipline; it might take some time for universities to change the perceptions and attitudes towards climate change.

However, as Akrofi et al (2019) argue, both the causes and effects would need to be key aspects for prompting engagement and thereby changing perceptions and attitudes. Considering the differences between the ages and study levels, this suggests that there may be benefits in creating initiatives that promote vicarious learning across multi-generational cohorts of students. This could potentially enhance the sharing of diverse personal experiences across geographic and cultural locations (Ayanlade and Jegede 2016). Nonetheless, involvement in environmental curricula or initiatives may not guarantee a change in climate change awareness or concern; as Mobley et al (2010) found over a decade ago, involvement in environmental organisations does not automatically mean that students will perceive that climate change is caused by human activity, and it may indeed promote other narratives that might undermine the possibility of human intervention (such as supernatural causes).

This study focuses on a better understanding of factors that shape perceptions of climate change, as well as the resulting levels of engagement in climate-positive actions. The study aimed to shed light on the underlying misconceptions that affect viewpoints about the plausibility of the phenomenon and (may) act as barriers to learning fundamental principles currently supported by scientific evidence and predictions. The factors examined in the study that shape students' perceptions and awareness levels should stimulate discussions among key stakeholders in the higher education institutions regarding the contents of and approaches to climate literacy pedagogy. Climate change education could adapt a variety of approaches in order to engage students about the nexus of climate risks and work towards a climate-literate society that is able to deal with the complexity of the defining issue of our time and to shape practical solutions (both in terms of mitigation and adaptation-resilience). As universities are in a unique position to be part of the solution, and drawing from student perceptions-engagement assessments, curriculum changes have to be considered in national contexts where the increase of students' knowledge and cognitive skills of the climate change awareness-engagement nexus is deemed imperative. Follow-up studies, drawing from larger international samples, could reveal whether curricular changes are required to ensure that all university graduates and postgraduates understand the scientific consensus about climate change. Given the ongoing debate on the specific context of global governance, key findings from international student surveys will continue to offer meaningful insights and encapsulate implications for national and international climate change education 
policies in order to foster desirable behavioural patterns in the next generation of decisionmakers over decarbonisation and climate-proofing.

\section{Conclusions}

Climate change is a serious global challenge, which requires the continuous, integrated and coordinated action of all sectors and societal actors. Knowledge about climate change, as well as perceptions and understanding about it, form the foundation that can avoid and or reduce its impacts. In this regard, universities are known to occupy a central position as centres for learning, innovation, and research to not only investigate and model climate change, but to also demonstrate climate change adaptation and mitigation measures. University graduates, if properly educated, could become change agents to influence the wider community. This is because awareness, which may be improved through training and information exposure, is a prerequisite for implementing wise adaptation and mitigation actions.

Climate change education in higher education is important, as it provides the knowledge and skills that bring about pro-environmental behavioural changes, leading to responsible, sustainable production and consumption patterns that will positively impact society at large, and may reduce the pressures caused by large $\mathrm{CO} 2$ emissions. The integration of climate issues in university education, co-curricular activities and research programmes should be emphasised so as to ensure that the next generation of professionals is duly aware of this global challenge and its many ramifications.

Universities can also, at the institutional level, better respond to climate change by applying environmentally-friendly and sustainable solutions in daily operational activities with the aim of reducing their direct impacts. HEl's climate commitments are mainly set as targets or goals to reduce their carbon emissions, which can occur through operational management, sustainability plans or climate action plans, or through a combination of these approaches.

This paper has identified very interesting evidence by examining the level of university students' awareness on climate change. Indeed, the findings of this study shed light on three significant research areas. Firstly, many of the university students seem to be aware of climate change risks. They acknowledge that climate change is mostly an outcome of human activity and not exclusively a regular natural process. It also appears that they trust universities to educate citizens regarding climate change risks. This implies a significant contribution to the discussion on social capital in relation to environmental problems, since there is a perceived need to mobilise higher education institutions towards global environmental problem-solving. Another important point highlighted by this study is the degree of students' concern about climate change risks. As expected, the awareness of university students is inextricably linked to their degree of familiarity with the topic, part of which is their participation in various climate change events.

Secondly, the findings show various views of university students from different regions concerning climate change risks. The findings suggest that university students from the Asia and Pacific region are more aware than those from other regions on climate change issues. This difference is probably associated with the variety of exposure of various regions to climate risks and, of course, the different levels of awareness of climate change risks among the university students in these regions.

Third, a differentiation regarding the knowledge of climate change risks is identified across gender, age and academic education. More female respondents shared the opinion that climate risks are an outcome of human activities than their male counterparts. Regarding the age of the respondents, it seems that the older university students have a better knowledge and higher awareness of climate risks. Furthermore, as it could be expected, university 
students within the field of environmental studies are more aware of climate change risks than students attending other courses.

As any other study, there are some limitations to this study. Although a significant number of questionnaires were collected in this survey from different countries, a larger number would be required to provide more robust trends in finer subcategories. In addition, the study did not entail interviews, a trend associated with the COVID-19 pandemic, which makes social contact more difficult. But despite these constraints, the study offers very useful insights into how university students perceive climate change.

Future studies should focus on further exploring the awareness of university students about particular themes, such as climate change risks, and comparing the views of the academic community in contrast with other sectors (e.g. industry).

It is hoped that this study will encourage more research that could strengthen the emphasis academic institutions give to climate change and help to catalyse more efforts into models of environmental behavior and psychology, which may in turn bring about a greater participation of university students in the handling of the many challenges posed by a changing climate.

\section{References}

AbuQamar, S., Alshannag, Q., Sartawi, A. \& Iratni, R.. Educational awareness of biotechnology issues among undergraduate students at the United Arab Emirates University. Biochemistry and Molecular Biology Education, 43, 4, 283-293. doi:10.1002/bmb.20863 (2015).

Agboola, O. S. \& Emmanuel, M.. Awareness of Climate Change and Sustainable Development among Undergraduates from Two Selected Universities in Oyo State, Nigeria. World Journal of Education, 6, 3, 70-81 (2016).

Akrofi, M.M., Antwi, S.H. \& Gumbo, J.R.. Students in climate action: a study of some influential factors and implications of knowledge gaps in Africa. Environments, 6(12), 1-15. doi:10.3390/environments6020012 (2019).

Altan, H. Energy efficiency intervention in UK higher education institutions, Energy Policy, 38, 7722-7731 (2010).

Ayanlade, S. \& Jegede, M.O.. Climate change education and knowledge among Nigerian university graduates. Weather, Climate, and Society, 465-473. doi: 10.1175/WCAS-D-150071.17 (2016).

Bakaç, E.. Engineering Faculty Students' Perceptions on Climate Change. Environment and Ecology Research, 6(4), 240- 247. doi: 10.13189/eer.2018.060404 (2018)

Barth, M. \& Rieckman, M.. A Review on Research in Higher Education for Sustainable Development. Paper presented at the $7^{\text {th }}$ World Environmental Education Congress, $9-14^{\text {th }}$ June 2013, Marrakech, Morocco (2013).

Beck, A., Sinatra, G.M. \& Lombardi, D. Leveraging higher-education instructors in the climate literacy effort factors related to university faculty's propensity to teach climate change. International Journal of Climate Change: Impacts and Responses, 4, 1-27. doi: 10.18848 /1835-7156/CGP/v04i0 4/37181. (2013). 
Burkholder, K.C., Devereaux, J., Grady, C., Solitro, M. \& Mooney, S.M. Longitudinal study of the impacts of a climate change curriculum on undergraduate student learning: initial results. Sustainability, 9(913), 1-28. doi:10.3390/su9060913 (2017).

Carlin, S.. Getting to the Heart of Climate Change Through Stories. In: Universities and Climate Change: Introducing Climate Change to University Programmes (Climate Change Management), Leal Filho, W. (ed). Springer: Berlin. pp 89-97 (2010).

Choi, Y.J., Oh, M., Kang. J. \& Lutzenhiser, L. Plans and Living Practices for the Green Campus of Portland State University" Sustainability 9, 2, 252. https://doi.org/10.3390/su9020252 (2017).

Cook, J., Oreskes, N., Doran, P. T., Anderegg, W. R. L., Verheggen, B., Maibach, E. W., Carlton, J. S., Lewandowsky, S., Skuce, A. G., Green, S. A., Nuccitelli, D., Jacobs, P., Richardson, M., Winkler, B., Painting, R. \& Rice, K. Consensus on consensus: a synthesis of consensus estimates on human-caused global warming. Environmental Research Letters, 11(4), 48002. doi: 10.1088/1748-9326/11/4/048002 (2016).

Cordero, E.C., Centeno, D. \& Todd, A.M. The role of climate change education on individual lifetime carbon emissions. PLoS ONE 15(2), e0206266. https://doi.org/10.1371/journal. (2020).

Cortese, A. D. The critical role of higher education in creating a sustainable future. Planning in Higher Education, 31(3), 15-22 (2003).

Cotton, D., Shiel, C.\& Paço, A. Energy Saving on Campus: A comparison of students' attitudes and reported behaviours in the UK and Portugal. Journal of Cleaner Production, $129,586-595$ (2016).

Dagiliūtè, R., Liobikienè, G. \& Minelgaitè, A. Sustainability at universities: Students' perceptions from green and non-green universities. Journal of Cleaner Production, 181, 473482 (2018).

Di Giusto, B., Lavallee, J. P. \& Yu, T. Y Towards an East Asian model of climate change awareness: A questionnaire study among university students in Taiwan. PLOS One, 13(10), e0206298. doi: 10.1371/journal.pone.0206298 (2018)

Eagle, L., Low, D., Case, P. \& Vandommele, L. Attitudes of undergraduate business students toward sustainability issues, International Journal of Sustainability in Higher Education, 16(5), 650-668. doi: 10.1108/IJSHE-04-2014-0054 (2015).

Filho, W. L. (Ed). 2010a. Universities and Climate Change: Introducing climate Change to University Programmes. Springer-Verlag Berlin Heidelberg: Berlin (2010a).

Filho, W. L., Shiel, C.\& Paço, A. Integrative approaches to environmental sustainability at universities: an overview of challenges and priorities. Journal of Integrative Environmental Sciences, 12(1), 1-14 (2015).

Filho, W.L., Salvia, A. L., do Paço, A., Anholon, R., Gonçalves Quelhas, O. L., Rampasso, I. S., Ng, A., Balogun, A.-L., Kondev, B .\& Brandli, L. L. A comparative study of approaches towards energy efficiency and renewable energy use at higher education institutions. Journal of Cleaner Production, 237, 117728. doi: 10.1016/j.jclepro.2019.117728 (2019a). 
Filho, W.L. Climate Change at Universities: Results of a World Survey. In: Universities and Climate Change: Introducing climate Change to University Programmes. Filho, W. L. (Ed). Springer-Verlag Berlin Heidelberg: Berlin. pp 1-19 (2010b).

Filho, W.L., Shiel, C., Paço, A., Mifsud, M., Ávila, L. V., Brandli, L. L., Molthan-Hill, P., Pace, P., Azeiteiro, U. M., Vargas, V. R. \& Caeiro, S. Sustainable Development Goals and sustainability teaching at universities: Falling behind or getting ahead of the pack? Journal of Cleaner Production, 232, 285-294. doi: 10.1016/j.jclepro.2019.05.309 (2019b)

Freije, A.M., Hussain, T. \& Salman, E.A. Global warming awareness among the University of Bahrain science students. Journal of the Association of Arab Universities for Basic and Applied Sciences, 22, 9-16 (2017).

Füssel, H. Vulnerability in Climate Change Research: A Comprehensive Conceptual Framework. UC Berkeley: University of California International and Area Studies. Retrieved 03-05-2021 https://escholarship.org/uc/item/8993z6nm 2005.

Fussel, H.M. \& Klein, R.J.T. Climate change vulnerability assessments: an evolution of conceptual thinking. Climatic Change, 75, 301-29 (2006).

Godwell, N. \& Nompe, N. Higher education institutions and carbon management: Cases from the UK and South Africa. Problems and Perspectives in Management, 12, 1, 218-227, (2014).

Grothmann, T.\& Patt, A. Adaptive capacity and human cognition: The process of individual adaptation to climate change. Global Environmental Change, 15, 199-213 (2005).

Haq, S.\& Ahmed, K. Perceptions about climate change among university students in Bangladesh. Natural Hazards, 103, 3683-3713. doi: 10.1007/s11069-020-04151-0 (2020).

Hauke, J. \& Kossowski, T. Comparison of values of Pearson's and Spearman's correlation coefficients on the same sets of data. Quaestiones geographicae, 30(2), 87-93 (2011).

Islam, S.N. \& Winkel, J. Climate Change and Social Inequality. DESA Working Paper No. 152. ST/ESA/2017/DWP/152. Retrieved 10-01-2021 from https://www.un.org/esa/desa/papers/2017/wp152 2017.pdf. (2017)

Kabir, M.I., Rahman, M.B., Smith, W., Lusha, M.A.F, Azim, S. \& Milton, A.H. Knowledge and perception about climate change and human health: findings from a baseline survey among vulnerable communities in Bangladesh. BMC Public Health, 16, 266. doi: 10.1186/s12889016-2930-3 (2016).

Katzy, B.R., Pawar, K.S \& Thoben, K.D. Editorial: A Living Lab Research Agenda. Int. J. Product Development, 17, 1/2, 1-8 (2021).

Knuth, S., Nagle, B., Steuer, C. \& Brent, Y. Universities and Climate Mitigation: Advancing Grassroots Climate Policy in the US. Local Environment, 12-5, 485-504 (2007).

Körfgen, A., Keller, L., Kuthe, A., Oberrauch, A. \& Stötter, H. (Climate) Change in young people's minds - From categories towards interconnections between the anthroposphere and natural sphere. Science of the Total Environment, 580, 178-187 (2017).

Kuthe, A., Körfgen, A., Stötter, J. \& Lars, L. Strengthening their climate change literacy: A case study addressing the weaknesses in young people's climate change awareness, 

10.1080/1533015X.2019.1597661 (2020).

Læssøe, J. \& Mochizuki, Y. Recent trends in national policy on education for sustainable development and climate change education. J Educ Sustain Dev. 9: 27-43.

Lapaige, V.\& Essiembre, H. Innoversity in knowledge-for-action and adaptation to climate change: the first steps of an 'evidence-based climatic health' transfrontier training program. Advances in Medical Education and Practice, 1, 89-105. doi: 10.2147/AMEP.S14027 (2010)

Larrán, Jorge, M., Andrades, Peña, F. J. \& Herrera Madueño, J. An analysis of university sustainability reports from the GRI database: an examination of influential variables. Journal of Environmental Planning and Management, 62(6), 1019-1044 (2019).

Liu, Q.\& Ren, J. Research on the building energy efficiency design strategy of Chinese universities based on green performance analysis. Energy and Buildings, 224, 110242. doi: 10.1016/j.enbuild.2020.110242 (2020).

Luepsen, $\mathrm{H}$. Comparison of nonparametric analysis of variance methods: A vote for van der Waerden. Communications in Statistics-Simulation and Computation, 47(9), 2547-2576 (2018).

Maxwell, J.\& Blashki, G. Teaching about climate change in medical education: an opportunity. Journal of Public Health Research, 5(1), 673 (2016).

Mobley, C., Vagias, W.\& DeWard, S. Exploring additional determinants of environmentally responsible behaviour: The infuence of environmental literature and environmental attitudes. Environment and Behavior, 42(4), 420-447 (2010).

Moggi, S. Social and environmental reports at universities: a Habermasian view on their evolution. Accounting Forum, 43(3), 283-326 (2019).

Molthan-Hill, P., Worsfold, N., Nagy, G.J., Leal Filho, W., Mifsud, M. Climate change education for universities: A conceptual framework from an international study. Journal of Cleaner Production, 226, 1092-1101 (2019).

Morgado, F., Bacelar-Nicolau, P., Rendon von Osten, J., Santos, P., Bacelar-Nicolau, L., Farooq, H., Alves, F., Soares, A.M.V.M. \& Azeiteiro, U.M. Assessing university student perceptions and comprehension of climate change (Portugal, Mexico and Mozambique). International Journal of Climate Change Strategies and Management, 9(3), 316-336, (2017).

Mugambiwa, S.S. \& Dzomonda, O., Climate change and vulnerability discourse by students at a South African university. Jàmbá: Journal of Disaster Risk Studies, 10(1), a476. doi: 10.4102/jamba.v10i1.476 (2018).

Myers, T.A., Maibach, E.W., Roser-Renouf, C., Akerlof, K. \& Leiserowitz, A.A. The relationship between personal experience and belief in the reality of global warming. Nature Climate Change, 3, 343-347 (2012).

Nigatu, A.S., Asamoah, B.O. \& Kloos, H. Knowledge and perceptions about the health impact of climate change among health sciences students in Ethiopia: a cross-sectional study. BMC Public Health, 14, 587. doi: 10.1186/1471-2458-14-587 (2014). 
Ojomo, E., Elliott, M., Amjad, U. \& Bartram, J. Climate change preparedness: a knowledge and attitudes study in Southern Nigeria. Environments, 2, 435-448. doi: 10.3390/environments2040435 (2015).

Owen, R., Fisher, E., McKenzie, K. beyond reduction: Climate change adaptation planning for universities and colleges. International Journal of Sustainability in Higher Education, 14(2), 46-160, (2013).

Pfautsch, S. \& Gray, T. Low factual understanding and high anxiety about climate warming impedes university students to become sustainability stewards: An Australian case study. International Journal of Sustainability in Higher Education, 18,(7), 1157-1175. doi: 10.1108/IJSHE-09-2016-0179 (2017).

Pitt, D. \& Congreve, A. Collaborative approaches to local climate change and clean energy initiatives in the USA and England. Local Environment, 22:9, 1124-1141 (2017).

Shahid, Z.\& Piracha, A. Awareness of Climate Change Impacts and Adaptation at Local Level in Punjab, Pakistan. In: Balanced Urban Development: Options and Strategies for Liveable Cities. Maheshwari B., Thoradeniya B., Singh V.P. (eds). Springer: Cham. doi: 10.1007/978-3-319-28112-4_25 (2016).

Shaman, J. \& Knowlton, K. The Need for Climate and Health Education. American Journal of Public Health, 108, S66-S67. doi: 10.2105/AJPH.2017.304045 (2017).

Shiel, C, Filho, W. L. , Paço, A., Brandlii, L. 2015. Evaluating the engagement of universities in capacity building for sustainable development in local communities. Evaluation and Programme Planning, 54, 123-134.

Skanavis, C., Kounani, A .\& Ntountounakis, I. Greek universities addressing the issue of climate change. In: Climate Change Research at Universities. Leal Filho, W. (ed). Springer: Cham. pp. 333-344 (2017).

Sterling, S., Maxey, L. \& Luna, H. (Eds). The Sustainable University: Progress and prospects. Routledge: Abingdon, Oxon (2013).

United Nations (1992). United Nations Framework Convention on Climate Change. New York: United Nations, General Assembly (2015).

United Nations Educational, Scientific and Cultural Organization (UNESCO). UNESCO strategy for the second half of the United Nations Decade of Education for Sustainable Development. Paris: UNESCO (2010).

van Valkengoed, A.M., Steg, L. 2019. Meta-analyses of factors motivating climate change adaptation behaviour. Nature Climate Change, 9, 158-163. doi: 10.1038/s41558-018-0371-y.

Vare, P. \& Scott, W. Learning for a change: Exploring the relationship between education and sustainable development. Journal of Education for Sustainable Development, 1(2), 191198 (2007).

Wachholz, S., Artz, N. \& Chene, D. Warming to the idea: university students' knowledge and attitudes about climate change. International Journal of Sustainability in Higher Education, 15(2), 128-141. doi: 10.1108/IJSHE-03-2012-0025 (2014). 
Yang, L., Liao, W., Liu, C., Zhang, N., Zhong, S. \& Huang, C. Associations between Survey of Medical, Public Health and Nursing Students in Universities in China. International Journal of Environmental Research and Public Health, 15(12), 2650. doi: 10.3390/ijerph15122650 (2018).

\section{Appendix A: Climate Change: Attitudes and Perceptions of University Students}

796

\section{Section 1 - Background}

1. Country:

2. Gender:
() $\mathrm{F}$
() $\mathrm{M}$
() Other

3. Age group:
( ) $18-25$
() $26-35$
() $36-50$
( ) $51+$

4. Study area:
( ) Education
( ) Arts and humanities
( ) Social sciences, journalism and information
() Business, administration and law
( ) Natural sciences, mathematics and statistics
() Information and communication technologies
( ) Engineering, manufacturing and construction
( ) Agriculture, forestry, fisheries and veterinary
( ) Health and welfare
( ) Services
( ) Other:

5. Current study level:
( ) Undergraduate
() Graduate
( ) Doctoral

6. Climate is...
() definitely changing
() probably changing
( ) I am not sure
( ) probably not changing
( ) definitely not changing

7. Climate change is...
( ) Caused entirely by human activity
() Caused mainly by human activity
( ) Caused equally by human activity and natural processes
( ) Caused mainly by natural processes
() Caused entirely by natural processes
( ) Definitely not happening

8. How worried are you about climate change?
( ) Extremely worried
() Very worried
( ) Somewhat worried
() Not very worried
( ) Not at all worried
() Climate change is not happening 
9. Where do you obtain information on climate change? (multiple answers possible)
( ) TV
( ) Radio
( ) Newspapers
() Social Media
( ) University
( ) Family
() Student Clubs/Associations
( ) NGOs
() Scientific database, like Scopus
( ) International Symposiums or events
( ) Other:

10. Perception and information on climate change: on the scale below mark your level of perception and information about climate change. ( $1=$ not at all; $5=$ to a great extent).

\begin{tabular}{|c|c|c|c|c|c|}
\hline 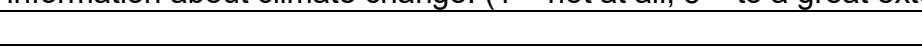 & 1 & 2 & 3 & 4 & 5 \\
\hline $\begin{array}{l}\text { To what extent are you aware of the differences between climate change } \\
\text { adaptation and mitigation? }\end{array}$ & & & & & \\
\hline To what extent are you update on the climate change debate? & & & & & \\
\hline $\begin{array}{l}\text { To what extent are you aware of the discussions and outcomes of the } \\
\text { Conferences of the Parties (COPs)? }\end{array}$ & & & & & \\
\hline $\begin{array}{l}\text { To what extent are you aware of the targets of the Sustainable } \\
\text { Development Goal (SDG) 13? }\end{array}$ & & & & & \\
\hline To what extent are you aware of the movement Fridays for the Future? & & & & & \\
\hline To what extent are you involved in the climate change movement? & & & & & \\
\hline
\end{tabular}

11. Is climate change present as a topic/subject in your course/teaching programme?
( ) Yes
( ) No

12. Level of emphasis to matters related to climate change in your course:
( ) The topic is very well covered with plenty of information
( ) The topic is covered with enough information
( ) The topic is not as well covered as we would like it to be
( ) The topic is poorly covered
( ) The topic is not covered at all
( ) I do not know/am not sure

13. More information about climate change in your university should come from: (multiple answers possible)
( ) Mandatory courses
( ) Optional courses
( ) Students' projects
() Publications
( ) Placements in companies
() Student clubs/associations
( ) University strategic plan
( ) Carrer centers
( ) Other:

14. In your opinion, which are the 3 main impacts caused by climate change (multiple choices possible):
( ) Damage to biodiversity
( ) Increase in the number of non-native species
() Increase in poverty
( ) Increase in conflict
( ) Sea-level rises
() Increase in number and severity of storms
( ) Increase in number and severity of droughts
() Melting of glaciers
( ) Flooding
() Increase in water-borne disease
( ) Increase in the displacement of communities
( ) Damage to infrastructure and superstructure
( ) Other (please specify) 
17. Which of the following problems hinder communication on climate change? (multiple choices possible)
( ) No problem at all
( ) The issue is too scientific
( ) The issue is too abstract
( ) The issue is too complex
( ) The issue has no connection with reality
( ) The issue does not affect me
( ) Impacts are too long term
( ) Other:

18. Would you like to participate in (more) activities related to climate change?
() Yes
( ) No

19. If so, in which ones?
() Students movements/protests for climate change awareness
( ) Training/capacity-building workshops
( ) Volunteerism/community activities
( ) Research on climate change
( ) More content about it in my course/teaching programme
( ) Other:

20. On which themes do you need further information? (multiple choices possible)
( ) Approaches to climate change mitigation
( ) Approaches to climate change adaptation
( ) Climate change causes and impacts
( ) Technologies that reduce climate change
( ) Sustainable Development Goal 13
( ) Other:

21. Greta Thunberg is a Swedish 17 year old student who has initiated School Strikes for Climate all around the world in an effort to raise awareness of the public and politicians about the climate change crisis. How do you feel about her efforts (choose the best three options):

( ) I am not aware of her actions

( ) I fully support her actions

( ) I have attended / organised School Strikes for Climate

( ) I wish I had the courage to do the same

( ) I feel that her actions have been successful

() I feel that her actions have not been successful

( ) I feel that she's doing all this to gain popularity

() I feel that she is being manipulated to serve the interests of others

( ) I feel that she is poorly informed about the complex nature of climate change

( ) Other (please specify) 


\section{Ethics Statement}

We confirm that in this research no experiments were undertaken with humans or human tissues or genetic materials. Data were collected through virtual platforms from experts in the area of climate change adaptation and mitigation in countries listed in the methods section. Besides, the research was not conducted based on the vulnerable group. We confirm all sources are duly acknowledged and the results reflect the authors" own research and analysis in a truthful and complete manner.

In this research, the questionnaire survey was carried out following the guidelines of the country of the first author, namely Germany, following the procedures used by the German Committee on Research Ethics (please see letter).

The survey participants' consent was requested before they were able to answer the questionnaire and their personal details of survey participants were not stored, and the respondents were anonymised. 


\section{ARBEITSKREIS MEDIZINISCHER ETHIK-KOMMISSIONEN}

IN DERR BUINDESREPPUIBLIK DI:UTS(HI.AND C. V.

To whom it may concern

Gräfelfing, 8.3.2021

\section{Manuscript: Attitudes and Perceptions of University Students on Climate Change: Evidences from an International Study}

First Author: Walter Leal et al.

I have checked the manuscript and certify herewith that the study mentioned above did and does not need to be reviewed by an Ethics Committee in Germany. There is no legal basis for Ethics Committees to review qualitative research with interviews, quantitative research using questionnaires or internet-based surveys. This type of research is free in agreement with the German base law.

Prof.Dr. Joerghastory $d$

President of the Association of Medical Ethics Committees in Germany
IORSITZFintR:

P'al' Dr med Jocen Ifusford

Hohik-Komminission dei

Bayconschen L andesirachaunume

Tet 49(0)80/808(6) $8(6) 7$

Fin $+40(0) 80 / 8080) \geq 17$

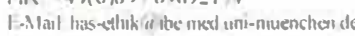

STEIII. I (ORSITY.FIISFE:

Piol I)r med (ieng Silhmid

Finh-hommission der Teclnischen

Inversitii Mlünchen

Fil $4(x) 180 / 41+107737$

Ias lox)

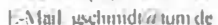

SC IIRIFTFÏIRER:

Prol Dr ien Schastian (inaf von Kiclmansege

SCIINICNIEISIFR:

Dr: med (iuclo (irass

IBEISITZR:

De. phil Angelihal Heiples

Prol Dr med Kut Rache

RAn Julin Rumler

Prot (Dr jur Jochen Thumitz

Prol Dr med lensz. Wessler

POSTASC HRIRT:

Schimintere Stußse 7

821 for citatelling

f-11111:

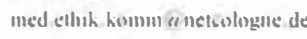

HONER:ICE:

www ah-med-cehih-komm de

BINRTONIO:

P'osthanh lianklunt ann Maun

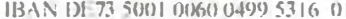
BIC PBNKDEFI

Fingeluagen in das V'ereinstegister heinn Amtsgerichu Berlim-( Tutsotenhurg unter $\backslash R \geqslant 1275 B$ 